\title{
An Evaluation of ISFET Sensors for Coastal pH Monitoring Applications
}

Karen McLaughlin ${ }^{1}$, Andrew Dickson ${ }^{2}$, Stephen B. Weisberg ${ }^{1}$, Kenneth Coale $^{3}$, Virginia Elrod ${ }^{4}$,

Craig Hunter ${ }^{3}$, Kenneth S. Johnson ${ }^{4}$, Susan Kram ${ }^{2 *}$, Raphael Kudela ${ }^{5}$, Todd Martz ${ }^{2}$, Kendra

Negrey $^{5}$, Uta Passow ${ }^{6}$, Frank Shaughnessy ${ }^{7}$, Jennifer E. Smith $^{2}$, Dawit Tadesse ${ }^{8}$, Libe

Washburn $^{6}$, Kyle R. Weis ${ }^{7}$

${ }^{1}$ Southern California Coastal Water Research Project Authority, Costa Mesa, CA 92626

${ }^{2}$ Scripps Institution of Oceanography, University of California San Diego, La Jolla, CA, 92093

${ }^{3}$ Moss Landing Marine Laboratories, 8272 Moss Landing Road, Moss Landing, CA 95039

${ }^{4}$ Monterey Bay Aquarium Research Institute, Moss Landing, CA, 95039

${ }^{5}$ University of California, Santa Cruz, CA 95064

${ }^{6}$ Marine Science Institute, University of California Santa Barbara, CA 93106

${ }^{7}$ Humboldt State University, Arcata, CA 95521

${ }^{8}$ California State Water Resources Control Board, Sacramento, CA 95814

*now at the University of California, San Francisco, 94143 


\begin{abstract}
The accuracy and precision of ion sensitive field effect transistor (ISFET) $\mathrm{pH}$ sensors have been well documented, but primarily by ocean chemistry specialists employing the technology at single locations. Here we examine their performance in a network context through comparison to discrete measurements of $\mathrm{pH}$, using different configurations of the Honeywell DuraFET $\mathrm{pH}$ sensor deployed in six coastal settings by operators with a range of experience. Experience of the operator had the largest effect on performance. The average difference between discrete and ISFET $\mathrm{pH}$ was $0.005 \mathrm{pH}$ units, but ranged from -0.030 to 0.083 among operators, with more experienced operators within $\pm 0.02 \mathrm{pH}$ units of the discrete measurement. In addition, experienced operators achieved a narrower range of variance in difference between discrete bottle measurements and ISFET sensor readings compared to novice operators and novice operators had a higher proportion of data failing quality control screening. There were no statistically significant differences in data uncertainty associated with sensor manufacturer or deployment environment (pier-mounted, flowthrough system, and buoy-mounted). The variation we observed among operators highlights the necessity of best practices and training when instruments are to be used in a network where comparison across data streams is desired. However, while opportunities remain for improving the performance of the ISFET sensors when deployed by less experienced operators, the uncertainty associated with their deployment and validation was several-fold less than the observed natural temporal variability in $\mathrm{pH}$, demonstrating the utility of these sensors in tracking local changes in acidification.
\end{abstract}

Keywords: $\mathrm{pH}$; sensor; ion sensitive field effect transistor (ISFET) $\mathrm{pH}$ sensors; acidification; monitoring network 


\section{Introduction}

Seawater $\mathrm{pH}$ is often used as a key parameter for understanding the impacts of ocean acidification (OA) on coastal ecosystems. These ecosystems are vulnerable to ecological and biogeochemical perturbations from OA (Doney et al. 2009, Howarth et al. 2011), which are affected by factors such as freshwater inputs, tidal forcing, water stratification, nutrient overenrichment, algal blooms, and hypoxia (Fabry et al. 2008, Borges and Gypens 2010). These perturbations may also take place within a background of acidification associated with the upwelling of low $\mathrm{pH}$ waters, such as on the U.S. West Coast. Thus, there is a trend towards increased monitoring of $\mathrm{pH}$ in coastal environments to both understand the inherent variability of coastal $\mathrm{pH}$ and aid in development of a mechanistic understanding of the roles of coastal feedbacks and interactions (Hofmann et al. 2011, Boehm et al. 2015).

Ion sensitive field effect transistor (ISFET) $\mathrm{pH}$ sensors have been shown to be stable and accurate for monitoring fine-scale changes in pH in seawater (Martz et al. 2010) and have rapidly become a preferred method for high frequency measurements of $\mathrm{pH}$ in ocean and nearshore monitoring (Hofmann et al. 2011, Kroeker et al. 2011, Yu et al. 2011, Johnson et al. 2016). They are also easy to deploy, requiring minimal maintenance during monthly or longer deployments, and deployable in a variety of habitat types (Hofmann et al. 2011). However, quantification of the accuracy and precision of ISFET sensors has primarily been conducted using individual instruments deployed by ocean chemistry specialists with a high degree of experience. While such studies provide understanding of temporal patterns at a particular site, ISFET instruments are increasingly being incorporated into monitoring networks for regional studies of spatial and temporal patterns [e.g., the California Current Acidification Network (McLaughlin et al. 2015), the Global Ocean Acidification Observing Network (Newton et al. 2014)]. Networked spatial 
comparisons can be confounded by the additional variability associated with use of sensors from different manufacturers, deployment in different habitat types, and the different levels of experience of the operator. Here we examine performance of ISFET sensors in a network context by comparing discrete measurements of $\mathrm{pH}$ to sensors deployed in a variety of environments at six coastal California sites by operators with a range of experience to gain insight into what additional uncertainty may be added across sites.

\section{Materials and Methods}

ISFET sensors were evaluated in two ways. First, we quantified the number of short-term errant spikes and extent of instrument drift at each site. Second, we compared instrument readings to discrete bottle samples, collected at the same time and in close proximity to the sensors, that were processed for $\mathrm{pH}$ using both a spectrophotometric indicator dye technique and calculated from simultaneous measurement of dissolved inorganic carbon (DIC) and total alkalinity (TA). Uncertainty in ISFET sensor measurements was then compared to the observed variability at the sites as indicated by the natural range of $\mathrm{pH}$ values observed during each deployment. Natural variability in $\mathrm{pH}$ at each site was defined as the range of $\mathrm{pH}$ encompassing $90 \%$ of all observed $\mathrm{pH}$ values.

Sensors

ISFET sensors were deployed at six nearshore locations along the California coast with a range of $\mathrm{pH}$ variability (Figure 1, Table 1); three were on stationary pier pilings (sites A, E, F), one on a moored buoy $(\mathrm{C})$, and two in a flowthrough stream from a pumped water source (B, D). 
Stationary pier piling sensors were mounted at depths of 1 to 4 meters (below the lowest, low tide line). The intake of the sensor at the moored, buoy sensor was at $20 \mathrm{~cm}$ depth (site C). Source water for the flowthrough system at site B was at the surface, and for site D was at 17 meters. Four of the sites were in coastal ocean waters (B, D, E, F), one in an enclosed bay (A) and one at the mouth of a small slough (C).

Independent operator groups deployed sensors, and collected and preserved discrete samples at each site. Of these groups, three were using the sensors for the first time (A, B, D) and are hereafter referred to as "novices". The remaining three had varying levels of prior experience with the instruments (C, E, F) and are hereafter referred to as "experienced".

Three configurations of the Honeywell DuraFET ISFET $\mathrm{pH}$ transducer were used among sites: (1) a commercially available system from Honeywell consisting of a DuraFET sensor (with internal chloride ion reference electrode) coupled to a controller box (Honeywell UDA2182), (2) a commercially available system from Satlantic ("SeaFET") consisting of a DuraFET and an external chloride ion selective reference electrode (wherein the external reference electrode was preferred except when salinity dropped below 20, due to unquantifiable uncertainties in the liquid junction potential), and (3) prototype versions of configuration (2) that were constructed in the Martz Lab at the Scripps Institution of Oceanography (SIO) and at the Monterey Bay Aquarium Research Institute (MBARI) (Martz et al. 2010). Sensors collected instantaneous pH measurements at variable frequencies depending on the site. All configurations of the ISFET included a thermistor. A subset of sites had co-located sensor packages collecting a variety of ancillary data including temperature, salinity, water depth (pressure), chlorophyll fluorescence, and dissolved oxygen (YSI 6600 data sonde, Sea Bird Electronics SBE37 Microcat, Sea Point 
chlorophyll fluoromenter). Methods of instrument calibration, maintenance and biofouling minimization are described in Table 1.

\section{Assessment of Sensor Operation}

Analysis of the rate of change in $\mathrm{pH}$ with time was conducted to inspect the data for three conditions: a) short-term, errant values that appear as unexplained spikes in the data record, b) sensor instability at the start of deployment (sensor conditioning - see below), and c) sensor failure that manifested as drift. Potentially errant $\mathrm{pH}$ measurements were flagged if the $\Delta \mathrm{pH} / \Delta \mathrm{t}$ $\left(\left[\mathrm{pH}_{\mathrm{i}}-\mathrm{pH}_{\mathrm{j}}\right] /\left[\mathrm{t}_{\mathrm{i}}-\mathrm{t}_{\mathrm{j}}\right]\right)$ over an interval of time exceeded \pm 2 standard deviations from the deployment mean $\Delta \mathrm{pH} / \Delta \mathrm{t}$. If the flagged interval occurred as an isolated, anomalous spike, the record was classified as errant. If $\mathrm{pH}$ values around the flagged interval occurred in a series of similarly high or low $\mathrm{pH}$ values (e.g., an event of high or low $\mathrm{pH}$ ), the record was maintained.

Sensor instability at the start of the deployment, likely due to reconditioning of the sensor in a new environment (Bresnahan et al. 2014), was indicated as the time period with highly variable $\Delta \mathrm{pH} / \Delta \mathrm{t}$ relative to the mean $\Delta \mathrm{pH} / \Delta \mathrm{t}$ at the beginning of the deployment and not otherwise associated with similar variability in temperature or salinity values over the same interval. Similarly, sensor drift due to biofouling or sensor failure (such as battery failure) was manifest as a segment of the time-series where measurements gradually decrease to improbable $\mathrm{pH}$ values $(<7.0$ at salinities exceeding 30$)$ or temperature measurements $\left(<0{ }^{\circ} \mathrm{C}\right)$. Values from sensors drifting due to sensor conditioning or other problems were deleted from the final dataset used to assess sensor performance (sensor measurements compared to bottle samples). Deleted segments for conditioning and drift included the series of values from the improbable value back 
to the portion of the dataset where the $\Delta \mathrm{pH} / \Delta \mathrm{t}$ value was consistently within two standard deviations of the mean $\Delta \mathrm{pH} / \Delta \mathrm{t}$.

\section{Discrete sample analysis}

Discrete samples were collected in close proximity (temporal and spatial) to sensor measurements in $500 \mathrm{~mL}$ Pyrex bottles. A single sample was collected for analysis of $\mathrm{pH}$ and total alkalinity (TA), and a separate sample was collected for dissolved inorganic carbon (DIC). For pier and buoy sites, separate samples for $\mathrm{pH} / \mathrm{TA}$ and DIC were collected from Niskin bottles, and for flowthrough sites water was pumped into consecutive bottles. All bottles were overfilled by a minimum of $250 \mathrm{~mL}$ leaving $\sim 1 \%$ headspace and preserved with $\sim 120 \mu \mathrm{L}$ of saturated mercury(II) chloride solution. Samples were sealed with a greased glass stopper secured with a rubber band and clip and stored at room temperature until analysis (Dickson et al. 2007). Field duplicates were conducted on $10 \%$ of the samples. Discrete samples were shipped to and analyzed by Dr. Andrew Dickson's Laboratory at the Scripps Institution of Oceanography, University of California, San Diego.

Discrete $\mathrm{pH}$ was quantified in two ways: spectrophotometrically using an indicator dye technique, and calculated from measurements of DIC and TA. The spectrophotometric $\mathrm{pH}$ technique was based on the method described by Carter et al. (2013), estimating $\mathrm{pH}$ at $25^{\circ} \mathrm{C}$ on the total hydrogen ion scale using purified $m$-cresol purple indicator dye and calibration equations developed by Liu et al. (2011). DIC was assayed by a gas extraction/coulometric procedure (Dickson et al. 2007) calibrated against seawater-based reference materials for which DIC had been certified by a vacuum extraction / manometric procedure (Dickson 2001). TA was 
determined by a two-stage, potentiometric, open-cell titration using coulometrically analyzed hydrochloric acid (Dickson et al. 2003). $\mathrm{CO}_{2}$ reference materials (produced by the Dickson Laboratory) were run as quality control for TA, DIC, and $\mathrm{pH}$. The $\mathrm{pH}$ was calculated from samples of DIC and TA using CO2calc version 1.2.8 and is reported on the total hydrogen ion concentration scale at in situ temperature (Robbins et al. 2010). The CO2calc program (and the measured data for TA) was also used to convert discrete, spectrophotomentric $\mathrm{pH}$ measurements to in situ temperatures. Program preferences were set to use carbonate system acid dissociation constants from Lueker et al. (2000), $\mathrm{KHSO}_{4}$ dissociation constants from Dickson et al. (1990), and total boron from Lee et al. (2010).

Differences between the paired discrete, bottle measurements of $\mathrm{pH}$ and ISFET sensor measurements were not normally distributed. Therefore, comparisons between sites with different operator experience level, ISFET sensor configuration, and deployment type were evaluated using non-parametric Mann-Whitney Rank Sum Tests (SigmaPlot 12.5).

\section{Results}

Assessment of Sensor Operation

Errant data points and short periods of malfunction were present at all sites, but there were four sites (Sites B, C, D, and F) for which greater than $95 \%$ of data met the quality control assessment (Table 2, Supplemental Figures 1 and 2). For these sites, most of the unusable data occurred towards the end of the deployment periods and may be attributable to biofouling. Two sites had extended periods of unusable data $(\mathrm{A}, \mathrm{E})$. The data set for Site $\mathrm{E}$ was generated by three different Satlantic sensors deployed in sequence, with most of the unusable data attributable to a 
single one of these sensors deployed between Dec 2012 and Mar 2013. This sensor functioned properly for about a month before exhibiting a sharp drift to improbable $\mathrm{pH}$ values that appeared unrelated to biofouling and were likely the result of instrument failure. The other two Satlantic sensors at Site E appeared to function appropriately throughout their respective deployments (Sep - Dec 2012 and Apr - Jun 2013, respectively). Site A was the only site to exhibit extreme variability in $\mathrm{pH}$ at the beginning of the time-series, likely due to conditioning to the deployment environment, it also exhibited drifts towards improbable $\mathrm{pH}$ values at least twice during the remainder of its deployment, yet was seemingly functional between these events.

Agreement between discrete $\mathrm{pH}$ measurement methods

The mean difference between the two independent discrete measures of $\mathrm{pH}$ (spectrophotometric and calculated from DIC and TA, $\Delta \mathrm{pH}^{m \mathrm{CP}-\mathrm{Calc}}, \mathrm{n}=203$ ) was -0.0154 with a spread ( $\pm 2 \sigma$ standard deviation) of $\pm 0.1038 \mathrm{pH}$ units (Table 3, Figure 2), comparable to what has been found by others in coastal settings (Hoppe et al. 2012, Wootton and Pfister 2012). Agreement between field duplicates for $\mathrm{pH}$ calculated from DIC and TA $(0.0074, \pm 2 \sigma= \pm 0.015$ $\mathrm{pH}$ units) was better than for field duplicates of $\mathrm{pH}$ estimated spectrophotometrically $(0.0114, \pm$ $2 \sigma= \pm 0.058 \mathrm{pH}$ units $)$

\section{Agreement between sensors and discrete pH measurements}

The mean difference between the spectrophotometric $\mathrm{pH}$ value $(m \mathrm{CP})$ and the ISFET sensor $\mathrm{pH}\left(\Delta \mathrm{pH}^{m \mathrm{CP}-\mathrm{FET}}\right)$ for all sites was 0.005 with a $\pm 2 \sigma$ standard deviation spread of \pm 0.155 pH units (Table 3). However, agreement between measures at a single site was variable. The 
sites with the best agreement (sites $\mathrm{C}$ and $\mathrm{F}$ ) had mean differences $\pm 2 \sigma$ less than $0.02 \pm 0.1 \mathrm{pH}$ units, while the site with the worst agreement (A) was over double that amount (mean difference $\pm 2 \sigma=0.05 \pm 0.23 \mathrm{pH}$ units) (Table 4, Figure 3). Most of the sites did not have a meaningful bias in the $\Delta \mathrm{pH}^{m \mathrm{CP}-\mathrm{FET}}$, with mean differences within $\pm 0.03 \mathrm{pH}$ units of 0 ; however, two sites (Sites A and E) had a consistent offset in the $\Delta \mathrm{pH}^{m \mathrm{CP}-\mathrm{FET}}$ where $m \mathrm{CP} \mathrm{pH}$ values were greater than 0.05 $\mathrm{pH}$ units higher than the ISFET $\mathrm{pH}$. There was a significant difference between experienced and novice groups in pier deployments and flowthrough systems (Mann-Whitney Rank Sum Test, Figures 4A and 4B). There was no significant difference between ISFET sensors in the SeaFET configuration (either the commercially available version from Satlantic or the prototype versions) and Honeywell configuration (comparing experienced deployments only, MannWhitney Rank Sum Test), nor for deployment environment: pier, flowthrough system, or buoy (comparing experienced deployments only, Mann-Whitney Rank Sum Test, Figure 4C).

The mean difference between the $\mathrm{pH}$ value calculated from DIC and TA and the ISFET sensor $\mathrm{pH}\left(\Delta \mathrm{pH}^{\text {calc-FET }}\right)$ across all sites was 0.021 (Table 3). Calculated $\mathrm{pH}$ and spectrophotometric $\mathrm{pH}$ demonstrated similar site to site variation in the difference between the laboratory $\mathrm{pH}$ and the ISFET $\mathrm{pH}$ (Table 4), with the notable exception of Site $\mathrm{C}$, where the calculated $\mathrm{pH}$ had nearly double the range of variability compared to the spectrophotometric $\mathrm{pH}$. This is likely attributable to the fact that the mooring at Site $\mathrm{C}$ is located at the mouth of a slough and the high organic carbon loading and/or contribution of non-carbonate anions to total alkalinity from the slough could interfere with calculation of $\mathrm{pH}$ (Hunt et al. 2011, Wootton and Pfister 2012).

\section{Discussion}


Calibrated ISFET sensors have been shown to operate with an accuracy of $0.01 \mathrm{pH}$ units or better on the total proton scale and have demonstrated stability over weeks to months of \pm $0.005 \mathrm{pH}$ units when deployed by experienced specialists (Martz et al. 2010, Johnson et al. 2016). However, we observed considerable instrument/operator-specific variability in agreement between the bottle measurements of $\mathrm{pH}$ and ISFET measures, particularly for first-time operators, with experienced operators having significantly greater accuracy and greater precision in sensor measurements compared to novice operators (Figures 4A and 4B).

Up to half the observed difference between sensors and discrete samples can be attributable to uncertainty associated with the discrete, reference sample measurement, as evidenced by the average $0.011 \mathrm{pH}$ unit difference between replicate $\mathrm{pH}$ samples collected by the same operator and the average $-0.015 \mathrm{pH}$ unit difference between the spectrophotometric and calculated measures. Previous research suggests one should be able to estimate $\mathrm{pH}$ on a discrete sample spectrophotometrically with an associated uncertainty of \pm 0.005 (Carter et al. 2013) and calculate $\mathrm{pH}$ from DIC and TA with an associated uncertainty of \pm 0.02 (Dickson and Riley 1978, Dickson et al. 2003); however, most coastal field studies report much higher uncertainty [0.01 to $0.05 \mathrm{pH}$ units (Wootton and Pfister 2012, Hammer et al. 2014)]. Some additional error could also be associated with where we collected the discrete sample, as the coastal ambient environment is characterized by considerable small-scale spatial and temporal variability (Frieder et al. 2012). Site D, for example, used a flowthrough system in which the validation sample was collected downstream of the sensor measurement and had a $\pm 2 \sigma$ standard deviation between laboratory standard and sensor $\mathrm{pH}$ of $\pm 0.1 \mathrm{pH}$ units (Table 4). This site also had one of the highest rates of ambient change in this study (an average of $0.084 \mathrm{pH}$ units per hour, Table 5). In this case, the rate of change in $\mathrm{pH}$ could impart an average difference of $0.01 \mathrm{in} \mathrm{pH}$ over 
the five minutes it could take to fill two discrete sample bottles for replicate analysis, which were collected in sequence from the flowthrough system, and could potentially impart a greater difference during periods of more rapid ambient $\mathrm{pH}$ change. In this study, the $\pm 2 \sigma$ standard deviation between laboratory measurement and sensor $\mathrm{pH}$ increases as the overall range of observed $\mathrm{pH}$ values increases, which may suggest that the spatial and temporal variability of $\mathrm{pH}$ may be a component of the difference between discrete and sensor values (Figure 5). Thus, an offset in time and/or space would be expected to impart a difference between bottle and sensed $\mathrm{pH}$ in nearshore areas, particularly those areas with large natural ranges in $\mathrm{pH}$.

The remainder of the observed differences between sensors and discrete samples appears to be attributable to operator error in use of the ISFET sensors, most of which was associated with calibration and biofouling/sensor malfunction. Best practices suggest a careful laboratorybased calibration point based on a discrete sample(s), following conditioning of the ISFET (Bresnahan et al. 2014). An extended conditioning period of the sensor to ambient water was only apparent at one site (site A), resulting in a large amount of early deployment data that failed quality control screening (Table 2). The sites that conducted a post-conditioning calibration performed better, though problems with calibration may contribute to a consistent bias in the difference between the discrete and sensor values (i.e., sites where the average difference was significantly different from zero). Novice sites had average differences between bottle and sensor $\mathrm{pH}$ greater than $\pm 0.03 \mathrm{pH}$ units, which may indicate some level of error that may be resolved through improved calibration. Very little additional uncertainty seems to be added by the sensors themselves, evidenced by the fact that the most experienced operators (Sites C and F) had average $\Delta \mathrm{pH}^{m \text { CP-ISFET }}$ and $\Delta \mathrm{pH}^{\text {Calc-ISFET }}$ that are indistinguishable from the average difference between replicate $\mathrm{pH}$ samples and the average $\Delta \mathrm{pH}^{m \mathrm{CP}-\mathrm{Calc}}$. 
Sensor drift towards the end of the deployments were apparent in all of the data sets to varying degrees, resulting in data loss during quality control screening (Table 2, Supplemental Figure 1). Bresnahan et al. (2014) have suggested co-deployment of another, independent pH sensor or other parameter sensor(s) that would be expected to co-vary with $\mathrm{pH}$ to monitor for sensor drift when confidence in data quality is critical.

While opportunities remain for improving the performance of the ISFET sensors when deployed by less experienced operators, the uncertainty associated with their deployment and validation was several-fold less than the natural temporal variability observed in this study. The 'natural' variability at each site, defined as the range of $\mathrm{pH}$ units encompassing $90 \%$ of all observed $\mathrm{pH}$ values, ranged from $0.57 \mathrm{pH}$ units to $0.22 \mathrm{pH}$ units, with an average of $0.39 \mathrm{pH}$

units (Table 5, Figure 6). Given the site with the best $\Delta \mathrm{pH}^{m \mathrm{CP}-\mathrm{FET}}$ is in the range of $0.01-0.02$ $\mathrm{pH}$ units, the ISFET sensors would be able to discern trends and patterns in environments with natural ranges greater than $0.1 \mathrm{pH}$ units. However, in a network context, where data may be present from multiple locations, uncertainty in spatial comparisons could be higher, as much as $0.2 \mathrm{pH}$ units, depending on the experience level of the participating operators.

\section{Conclusions}

ISFET sensors can provide information on high frequency $\mathrm{pH}$ variability within defined error limits in nearshore marine deployments given appropriate experience with sensors and use of best practices to ensure data quality. Nevertheless, operators should be cautioned that operator error appears to be a defining factor in generating usable data with an ISFET sensor. Operator errors in collecting and analyzing discrete samples, as well as improper calibration and 
deployment of the ISFET, are factors that can be mitigated through training and use of best practices (Bresnahan et al. 2014, Rivest et al. 2016). This study suggests that differences between calibrated sensor $\mathrm{pH}$ values and values obtained from discrete, check samples can be expected to be as small as $0.02 \mathrm{pH}$ units, and perhaps less. Given this, most sites would be expected to recover data with uncertainties that reflect those of the highest-performing sites in this study. Best practices to identify and reduce sensor measurement error related bio-fouling will improve data recovery. Our experience supports the Bresnahan et al. (2014) recommendation that codeployment of at least one other independent sensor would provide confirmation that the sensors are not drifting and greatly improve confidence in data quality.

\section{Acknowledgements}

Funding for the laboratory analysis of discrete $\mathrm{pH}$ was from the California State Water Resources Control Board. Deployments of ISFET sensors were funded by the National Science Foundation (NSF) through RAPID award OCE1251573, and through the NOAA ECOHAB program through award NA11NOS4780030 to RK, NSF award OCE-1041038 to UP, grants from the David and Lucile Packard Foundation and the National Ocean Partnership Program to $\mathrm{KJ}$, and from generous donations from the Ellen Browning Scripps Foundation and the Scripps Family Foundation to JES. The authors would also like to thank the Southern California Coastal Ocean Observing System (SCCOOS) and the Central and Northern California Coastal Ocean Observing System (CeNCOOS) for their support of this project. This paper was improved by comments from Editor Dr. Gunnar Lauenstein and two anonymous reviewers. 


\section{References and Citations}

Boehm, A. B., M. Z. Jacobson, M. J. O’Donnell, M. Sutula, W. W. Wakefield, S. B. Weisberg, and E. Whiteman. 2015. Ocean acidification science needs for natural resource managers of the North American West Coast. Oceanography 28.

Borges, A. V. and N. Gypens. 2010. Carbonate chemistry in the coastal zone responds more strongly to eutrophication than to ocean acidification. Limnology and Oceanography 55:346-353.

Bresnahan, P. J., T. R. Martz, Y. Takeshita, K. S. Johnson, and M. LaShomb. 2014. Best practices for autonomous measurement of seawater $\mathrm{pH}$ with the Honeywell DuraFET. Methods in Oceanography 9:44-60.

Carter, B. R., J. A. Radich, H. L. Doyle, and A. G. Dickson. 2013. An automated system for spectrophotometric seawater $\mathrm{pH}$ measurements. Limnology and Oceanography-Methods 11:16-27.

Dickson, A. and J. Riley. 1978. The effect of analytical error on the evaluation of the components of the aquatic carbon-dioxide system. Marine Chemistry 6:77-85.

Dickson, A. G. 2001. Reference materials for oceanic measurements. Oceanography 14:21-22.

Dickson, A. G., J. D. Afghan, and G. C. Anderson. 2003. Reference materials for oceanic $\mathrm{CO}_{2}$ analysis: A method for the certification of total alkalinity. Marine Chemistry 80:185-197.

Dickson, A. G., C. L. Sabine, and J. R. Christian, editors. 2007. Guide to best practices for ocean $\mathrm{CO}_{2}$ measurements. 
Dickson, A. G., D. J. Wesolowski, D. A. Palmer, and R. E. Mesmer. 1990. Dissociation constant of bisulfate ion in aqueous sodium chloride solutions to 250 degree C. Journal of Physical Chemistry 94:7978-7985.

Doney, S. C., V. J. Fabry, R. A. Feely, and J. A. Kleypas. 2009. Ocean acidification: The other $\mathrm{CO}_{2}$ problem. Pages 169-192 Annual Review of Marine Science. Annual Reviews, Palo Alto.

Fabry, V. J., B. A. Seibel, R. A. Feely, and J. C. Orr. 2008. Impacts of ocean acidification on marine fauna and ecosystem processes. ICES Journal of Marine Science: Journal du Conseil 65:414-432.

Frieder, C. A., S. H. Nam, T. R. Martz, and L. A. Levin. 2012. High temporal and spatial variability of dissolved oxygen and $\mathrm{pH}$ in a nearshore California kelp forest. Biogeosciences 9:3917-3930.

Hammer, K., B. Schneider, K. Kuliński, and D. E. Schulz-Bull. 2014. Precision and accuracy of spectrophotometric $\mathrm{pH}$ measurements at environmental conditions in the Baltic Sea. Estuarine, Coastal and Shelf Science 146:24-32.

Hofmann, G. E., J. E. Smith, K. S. Johnson, U. Send, L. A. Levin, F. Micheli, A. Paytan, N. N. Price, B. Peterson, and Y. Takeshita. 2011. High-frequency dynamics of ocean pH: A multi-ecosystem comparison. Plos One 6:e28983.

Hoppe, C. J. M., G. Langer, S. D. Rokitta, D. A. Wolf-Gladrow, and B. Rost. 2012. Implications of observed inconsistencies in carbonate chemistry measurements for ocean acidification studies. Biogeosciences 9:2401-2405. 
Howarth, R., F. Chan, D. J. Conley, J. Garnier, S. C. Doney, R. Marino, and G. Billen. 2011. Coupled biogeochemical cycles: Eutrophication and hypoxia in temperate estuaries and coastal marine ecosystems. Frontiers in Ecology and the Environment 9:18-26.

Hunt, C., J. Salisbury, and D. Vandemark. 2011. Contribution of non-carbonate anions to total alkalinity and overestimation of $\mathrm{pCO}_{2}$ in New England and New Brunswick rivers. Biogeosciences 8:3069-3076.

Johnson, K. S., H. W. Jannasch, L. J. Coletti, V. A. Elrod, T. R. Martz, Y. Takeshita, R. J. Carlson, and J. G. Connery. 2016. Deep-sea DuraFET: A pressure tolerant pH sensor designed for global sensor networks. Analytical Chemistry 88:3249-3256.

Kroeker, K. J., F. Micheli, M. C. Gambi, and T. R. Martz. 2011. Divergent ecosystem responses within a benthic marine community to ocean acidification. Proceedings of the National Academy of Sciences 108:14515-14520.

Lee, K., T.-W. Kim, R. H. Byrne, F. J. Millero, R. A. Feely, and Y.-M. Liu. 2010. The universal ratio of boron to chlorinity for the North Pacific and North Atlantic oceans. Geochimica Et Cosmochimica Acta 74:1801-1811.

Liu, X., M. C. Patsavas, and R. H. Byrne. 2011. Purification and charaterization of meta-cresol purple for spectrophotometric seawater $\mathrm{pH}$ measurements. Environmental Science and Technology 45:4862-4868.

Lueker, T. J., A. G. Dickson, and C. D. Keeling. 2000. Ocean pCO(2) calculated from dissolved inorganic carbon, alkalinity, and equations for k-1 and k-2: Validation based on laboratory measurements of $\mathrm{CO}_{2}$ in gas and seawater at equilibrium. Marine Chemistry 70:105-119. 
Martz, T. R., J. G. Connery, and K. S. Johnson. 2010. Testing the Honeywell DuraFET® for seawater $\mathrm{pH}$ applications. Limnology Oceanography Methods 8:172-184.

McLaughlin, K., S. B. Weisberg, A. G. Dickson, G. E. Hofmann, J. A. Newton, D. AseltineNeilson, A. Barton, S. Cudd, R. A. Feely, I. W. Jefferds, E. B. Jewett, T. King, C. Langdon, S. McAfee, D. Pleschner-Steele, and B. Steele. 2015. Core principles for a nearshore marine acidification monitoring network: Linking chemistry, physics and ecological effects. Oceanography 28:160-169.

Newton, J. A., R. A. Feely, E. B. Jewett, J. Williamson, and J. Mathis. 2014. Global Ocean Acidification Observing Network: Requirements and governance plan. http://www.goaon.org/docs/GOA-ON_plan_print.pdf.

Rivest, E. B., M. O'Brien, L. Kapsenberg, C. C. Gotschalk, C. A. Blanchette, U. Hoshijima, and G. E. Hofmann. 2016. Beyond the benchtop and the benthos: Dataset management planning and design for time series of ocean carbonate chemistry associated with DuraFET@-based pH sensors. Ecological Informatics.

Robbins, L. L., M. E. Hansen, J. A. Kleypas, and S. C. Meylan. 2010. CO2calc-- a user friendly seawater carbon calculator for Windows, Mac OSX, and iOS (iPhone): U.S. Geological Survey open-file report 2010-1280.

Wootton, J. T. and C. A. Pfister. 2012. Carbon system measurements and potential climatic drivers at a site of rapidly declining ocean pH. Plos One 7:e53396.

Yu, P. C., P. G. Matson, T. R. Martz, and G. E. Hofmann. 2011. The ocean acidification seascape and its relationship to the performance of calcifying marine invertebrates: Laboratory experiments on the development of urchin larvae framed by environmentallyrelevant $\mathrm{pCO}_{2} / \mathrm{pH}$. Journal of Experimental Marine Biology and Ecology 400:288-295. 
Table 1. Sampling locations and sensor information

\begin{tabular}{|c|c|c|c|c|c|c|}
\hline Site Location & Sensor & $\begin{array}{l}\text { Sample } \\
\text { Frequency }\end{array}$ & Calibration & $\begin{array}{l}\text { Biofouling } \\
\text { Counter-Measures }\end{array}$ & Maintenance & Discrete Sample Collection \\
\hline $\begin{array}{l}\text { Pier-Mounted Site A } \\
\text { Humboldt Bay, Chevron Dock } \\
(40.7776 \text { and }-124.1965) \\
\text { Novice }\end{array}$ & $\begin{array}{l}\text { Honeywell } \\
\text { DuraFET III }\end{array}$ & 5 mins & $\begin{array}{l}\text { Two point } \\
\text { calibrations } \\
\text { performed in } 7.0 \\
\text { and } 10.0 \mathrm{pH} \\
\text { buffer solutions }\end{array}$ & $\begin{array}{l}\text { Biofouling removed } \\
\text { every } 21-28 \text { days } \\
\text { during calibration }\end{array}$ & $\begin{array}{l}\text { Sensor cleaned and } \\
\text { maintained according to } \\
\text { manufacturer } \\
\text { specifications once every } \\
21-28 \text { days. }\end{array}$ & $\begin{array}{l}\text { Discrete sample collected at } \\
\text { sensor deployment depth with } \\
\text { Wildco 2.2L Alpha Horizontal } \\
\text { Sampler and subsampled in to } \\
\text { the Pyrex bottle through a } \\
\text { Tygon tube }\end{array}$ \\
\hline $\begin{array}{l}\text { Flowthrough Site B } \\
\text { Santa Cruz Wharf } \\
(36.9603 \text { and }-122.0203) \\
\text { Novice }\end{array}$ & $\begin{array}{l}\text { Satlantic } \\
\text { Ocean pH } \\
\text { sensor }\end{array}$ & 5 mins & $\begin{array}{l}\text { Calibrated to } \\
\text { regression line } \\
\text { developed with } \\
\text { pH standards } 7 \\
\text { and } 10\end{array}$ & $\begin{array}{l}\text { Copper guard } \\
\text { provided by } \\
\text { Satlantic with the } \\
\text { SeaFET sensor }\end{array}$ & $\begin{array}{l}\text { Sensor fouling removed } \\
\text { weekly }\end{array}$ & $\begin{array}{l}\text { Discrete sample draw from } \\
\text { flowthrough system conducted } \\
5 \mathrm{~cm} \text { downstream of sensor }\end{array}$ \\
\hline $\begin{array}{l}\text { Buoy Site C } \\
\text { Elkhorn Slough } \\
(36.8078 \text { and }-121.7710) \\
\text { Experienced }\end{array}$ & $\begin{array}{l}\text { Prototype } \\
\text { SeaFET } \\
\text { Ocean pH } \\
\text { sensor }\end{array}$ & 60 mins & $\begin{array}{l}\text { Calibrated in } \\
\text { TRIS; TRIS pH } \\
\text { validated with m- } \\
\text { cresol purple dye } \\
\text { method }\end{array}$ & $\begin{array}{l}\text { Water was pumped } \\
\text { through copper/ } \\
\text { nickel tubing from } \\
\text { the intake to the } \mathrm{pH} \\
\text { flow cell }\end{array}$ & $\begin{array}{l}\text { Sensor rinsed with } \\
\text { ambient water every two } \\
\text { months; Occasionally } \\
\text { rinsed with freshwater or } \\
\text { dilute hydrochloric acid } \\
\text { and wiped with a cotton } \\
\text { tipped applicator as } \\
\text { necessary. }\end{array}$ & $\begin{array}{l}\text { Discrete samples collected in } \\
\text { proximity to buoy in } 2.5 \mathrm{~L} \\
\text { Niskin bottle and subsampled } \\
\text { in to the Pyrex bottle through a } \\
\text { Tygon tube }\end{array}$ \\
\hline $\begin{array}{l}\text { Flowthrough Site D } \\
\text { Moss Landing Marine Labs } \\
\text { (36.8025 and -121.7915) } \\
\text { Experienced }\end{array}$ & $\begin{array}{l}\text { Honeywell } \\
\text { DuraFET III }\end{array}$ & 15 mins & $\begin{array}{l}\text { Calibrated to } \\
\text { regression line } \\
\text { developed with } \\
\text { pH standards } 6 \\
\text { and } 10 \text { as well as } \\
\text { Tris and AMP } \\
\text { buffers }\end{array}$ & $\begin{array}{l}\text { Water was pumped } \\
\text { through copper/ } \\
\text { nickel tubing }\end{array}$ & $\begin{array}{l}\text { Sensor cleaned and } \\
\text { maintained according to } \\
\text { manufacturer } \\
\text { specifications once or } \\
\text { twice monthly depending } \\
\text { on sediment load }\end{array}$ & $\begin{array}{l}\text { Discrete sample draw from } \\
\text { flowthrough system conducted } \\
5 \mathrm{~cm} \text { downstream of sensor }\end{array}$ \\
\hline $\begin{array}{l}\text { Pier-Mounted Site E } \\
\text { Santa Barbara, Sterns Wharf } \\
(34.4092 \text { and }-119.6847) \\
\text { Novice }\end{array}$ & $\begin{array}{l}\text { Satlantic } \\
\text { Ocean } \mathrm{pH} \\
\text { sensor }\end{array}$ & 15 mins & $\begin{array}{l}\text { Calibrated in situ } \\
\text { from parallel } \\
\text { measurements }\end{array}$ & $\begin{array}{l}\text { Flow through } \\
\text { copper caps were } \\
\text { installed over the } \\
\text { SeaFET electrodes. } \\
\text { Pressure cases were } \\
\text { wrapped in tape to } \\
\text { remove bio-fouling } \\
\text { after recovery }\end{array}$ & $\begin{array}{l}\text { Sensor cleaned and } \\
\text { maintained according to } \\
\text { manufacturer } \\
\text { specifications every three } \\
\text { months }\end{array}$ & $\begin{array}{l}\text { Discrete samples collected in } \\
\text { proximity to sensor deployment } \\
\text { (horizontal and depth } \\
\text { proximity) in } 2 \text { L Niskin bottle } \\
\text { and subsampled in to the Pyrex } \\
\text { bottle through a Tygon tube }\end{array}$ \\
\hline $\begin{array}{l}\text { Pier-Mounted Site F } \\
\text { Scripps Pier (32.8669 and - } \\
117.2574) \\
\text { Experienced }\end{array}$ & $\begin{array}{l}\text { Prototype } \\
\text { SeaFET } \\
\text { Ocean pH } \\
\text { sensor }\end{array}$ & 15 mins & $\begin{array}{l}\text { Calibrated in } \\
\text { TRIS; TRIS pH } \\
\text { validated with m- } \\
\text { cresol purple dye } \\
\text { method }\end{array}$ & $\begin{array}{l}\text { Copper mesh guard } \\
\text { placed around the } \\
\text { SeaFET sensor to } \\
\text { prevent biofouling }\end{array}$ & $\begin{array}{l}\text { Sensor cleaned and } \\
\text { maintained according to } \\
\text { manufacturer } \\
\text { specifications every two } \\
\text { months }\end{array}$ & $\begin{array}{l}\text { Discrete samples collected in } \\
\text { proximity to sensor deployment } \\
\text { (horizontal and depth } \\
\text { proximity) in } 2 \text { L Niskin bottle } \\
\text { and subsampled in to the Pyrex } \\
\text { bottle through a Tygon tube }\end{array}$ \\
\hline
\end{tabular}


Table 2. Data quality screening results for each site.

\begin{tabular}{|l|c|c|c|c|}
\hline Station & $\begin{array}{c}\text { Dataset \% complete } \\
\text { after QA }\end{array}$ & $\begin{array}{c}\text { \% Eliminated at Start } \\
\text { of Deployment } \\
\text { Conditioning Issue) }\end{array}$ & $\begin{array}{c}\text { \% Eliminated Due to } \\
\text { Drift to Improbable } \\
\text { Values }\end{array}$ & $\begin{array}{c}\text { \% Eliminated Due to } \\
\text { Rogue Data Points }\end{array}$ \\
\hline $\begin{array}{l}\text { Pier-Mounted } \\
\text { Site A }\end{array}$ & $34 \%$ & $40 \%$ & $26 \%$ & $0.1 \%$ \\
\hline $\begin{array}{l}\text { Flowthrough } \\
\text { Site B }\end{array}$ & $96 \%$ & $0 \%$ & $4 \%$ & $0.1 \%$ \\
\hline $\begin{array}{l}\text { Buoy } \\
\text { Site C }\end{array}$ & $99 \%$ & $0 \%$ & $1 \%$ & $0.05 \%$ \\
\hline $\begin{array}{l}\text { Flowthrough } \\
\text { Site D }\end{array}$ & $96 \%$ & $0 \%$ & $4 \%$ & $0.05 \%$ \\
\hline $\begin{array}{l}\text { Pier-Mounted } \\
\text { Site E }\end{array}$ & $71 \%$ & $0 \%$ & $29 \%$ & $0.01 \%$ \\
\hline $\begin{array}{l}\text { Pier-Mounted } \\
\text { Site F }\end{array}$ & $>99 \%$ & $0 \%$ & $0 \%$ & $0.05 \%$ \\
\hline
\end{tabular}


Table 3. Sensor $\mathrm{pH}$ range and performance relative to discrete measures of $\mathrm{pH}$.

\begin{tabular}{|c|c|c|}
\hline Comparison & $\mathbf{n}$ & $\operatorname{Mean} \Delta \pm 2 \sigma$ \\
\hline $\begin{array}{l}\text { Comparison of Field Replicates } \\
m \text { CP rep - } m \text { CP Rep (Dickson Lab) } \\
\text { calculated rep - calculated rep }\end{array}$ & $\begin{array}{l}23 \\
24\end{array}$ & $\begin{array}{l}0.0114 \pm 0.058 \\
0.0074 \pm 0.015\end{array}$ \\
\hline $\begin{array}{l}\text { Comparison of Discrete pH Measures } \\
m \mathrm{CP}-\text { calculated }\left(\Delta \mathrm{pH}^{m \mathrm{CP}-\mathrm{Cal} c}\right)\end{array}$ & 203 & $-0.0154 \pm 0.1038$ \\
\hline $\begin{array}{l}\text { Comparison of Discrete pH to Sensor pH } \\
\text { Dickson } m \text { CP }- \text { ISFET }\left(\Delta \mathrm{pH}^{m \mathrm{CP}-\mathrm{FET}}\right) \\
\text { calculated }-\mathrm{ISFET}\left(\Delta \mathrm{pH}^{\mathrm{Calc}-\mathrm{FET}}\right)\end{array}$ & $\begin{array}{l}163 \\
166\end{array}$ & $\begin{array}{l}0.005 \pm 0.155 \\
0.021 \pm 0.147\end{array}$ \\
\hline
\end{tabular}


Table 4. Site by site comparison of sensor performance relative to discrete standard

\begin{tabular}{|c|c|c|c|}
\hline Station & $\begin{array}{c}\text { Mean } \Delta \pm 2 \sigma \\
m \mathrm{CP} \text { pH - calculated } \\
\text { pH (DIC and TA }) \\
\left(\Delta \mathrm{pH}^{m \mathrm{CP}-\text { calc }}\right)\end{array}$ & $\begin{array}{c}\text { Mean } \Delta \pm 2 \sigma \\
m \mathrm{CP} \text { pH - ISFET pH } \\
\left(\Delta \mathrm{pH}^{m \mathrm{CP}-\mathrm{FET}}\right)\end{array}$ & $\begin{array}{c}\text { Mean } \Delta \pm 2 \sigma \\
\text { calculated pH - } \\
\text { ISFET pH } \\
\left(\Delta \text { pH }^{\text {Calc-FET }}\right)\end{array}$ \\
\hline $\begin{array}{l}\text { Pier-Mounted Site } \\
\text { A }\end{array}$ & $-0.001 \pm 0.055$ & $0.048 \pm 0.230$ & $0.076 \pm 0.215$ \\
\hline $\begin{array}{l}\text { Flowthrough Site } \\
\text { B }\end{array}$ & $-0.013 \pm 0.066$ & $-0.030 \pm 0.138$ & $-0.019 \pm 0.149$ \\
\hline $\begin{array}{l}\text { Buoy } \\
\text { Site C }\end{array}$ & $-0.009 \pm 0.099$ & $-0.012 \pm 0.078$ & $0.002 \pm 0.140$ \\
\hline $\begin{array}{l}\text { Flowthrough Site } \\
\text { D }\end{array}$ & $-0.028 \pm 0.090$ & $0.011 \pm 0.101$ & $-0.039 \pm 0.146$ \\
\hline $\begin{array}{l}\text { Pier-Mounted Site } \\
\text { E }\end{array}$ & $-0.012 \pm 0.057$ & $0.083 \pm 0.104$ & $0.089 \pm 0.099$ \\
\hline $\begin{array}{l}\text { Pier-Mounted Site } \\
\text { F }\end{array}$ & $-0.020 \pm 0.067$ & $-0.020 \pm 0.063$ & $-0.004 \pm 0.058$ \\
\hline
\end{tabular}


Table 5. Range of $\mathrm{pH}$ conditions encountered at the six test sites.

\begin{tabular}{|c|c|c|c|c|}
\hline Station & Max pH & $\begin{array}{c}\text { Min } \\
\text { pH }\end{array}$ & $\begin{array}{c}\text { Average } \\
\Delta \mathrm{pH} / \Delta \mathrm{t} \\
\left(\mathrm{pH} \text { units hr } \mathbf{~}^{-1}\right)\end{array}$ & $\begin{array}{c}\text { pH range } \\
\text { between the } 5^{\text {th }} \\
\text { and } 95^{\text {th }} \\
\text { percentile }\end{array}$ \\
\hline Pier-Mounted Site A & 8.52 & 7.55 & 0.051 & 0.57 \\
\hline Flowthrough Site B & 8.40 & 7.58 & 0.017 & 0.42 \\
\hline Buoy Site C & 8.37 & 7.43 & 0.031 & 0.30 \\
\hline Flowthrough Site D & 8.33 & 7.10 & 0.084 & 0.48 \\
\hline Pier-Mounted Site E & 8.21 & 7.43 & 0.024 & 0.35 \\
\hline Pier-Mounted Site F & 8.30 & 7.56 & 0.014 & 0.22 \\
\hline
\end{tabular}




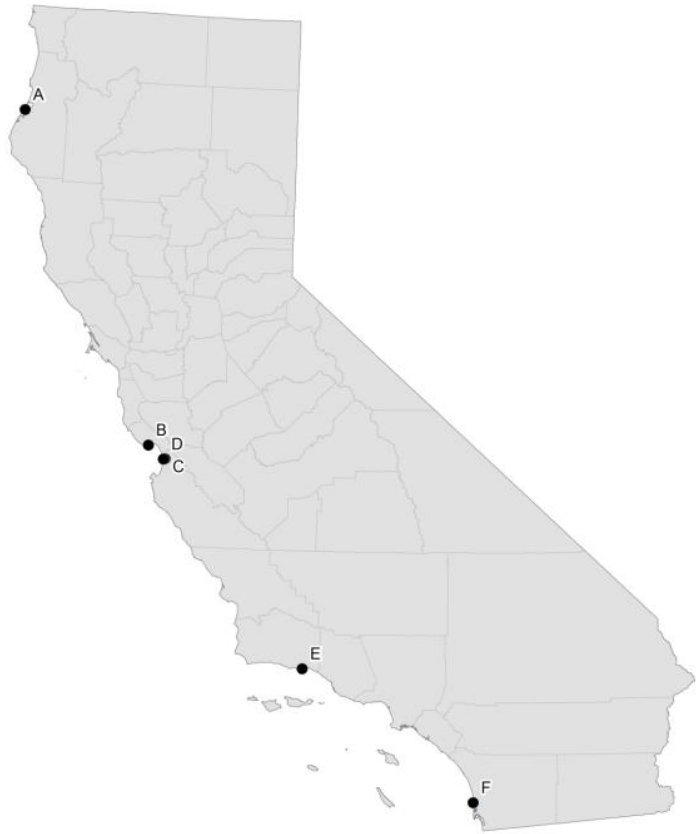

Figure 1. Location of ISFET deployments along California coastline. 


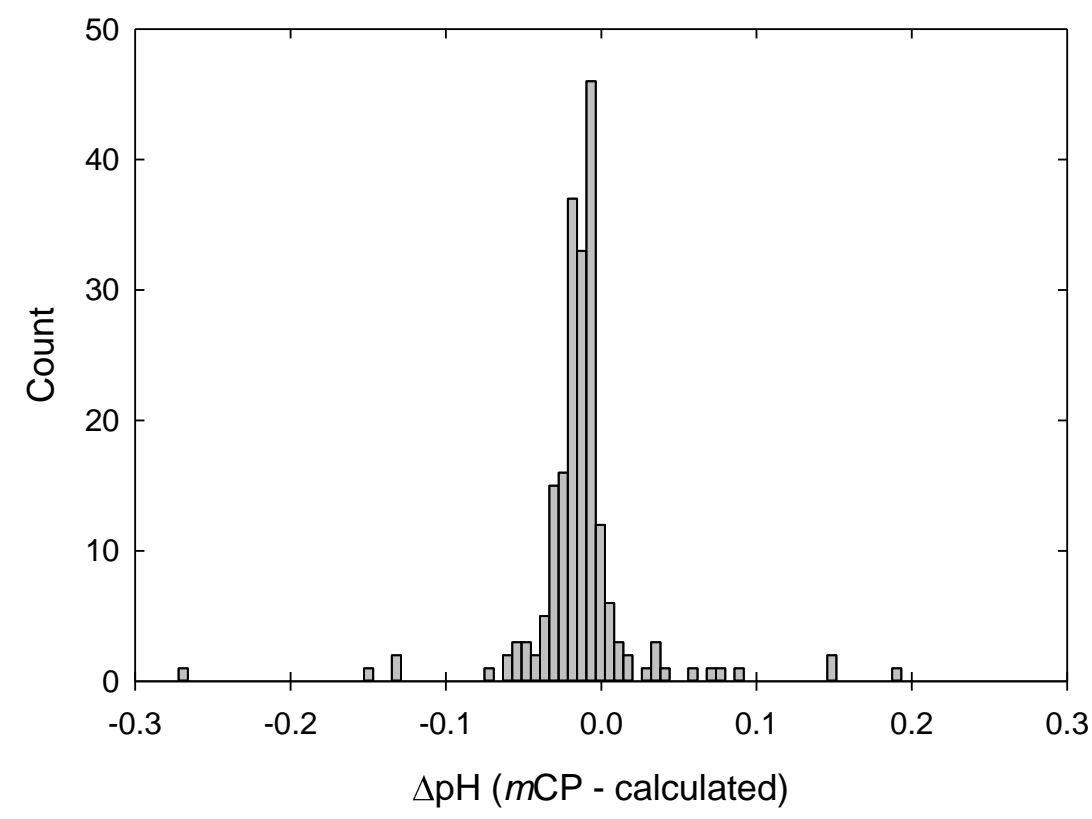

Figure 2. Comparison of discrete, bottle $\mathrm{pH}$ measurements made using the $m$-cresol purple indicator dye method and discrete, bottle $\mathrm{pH}$ values calculated from measurements of dissolved inorganic carbon and total alkalinity for all sites. 


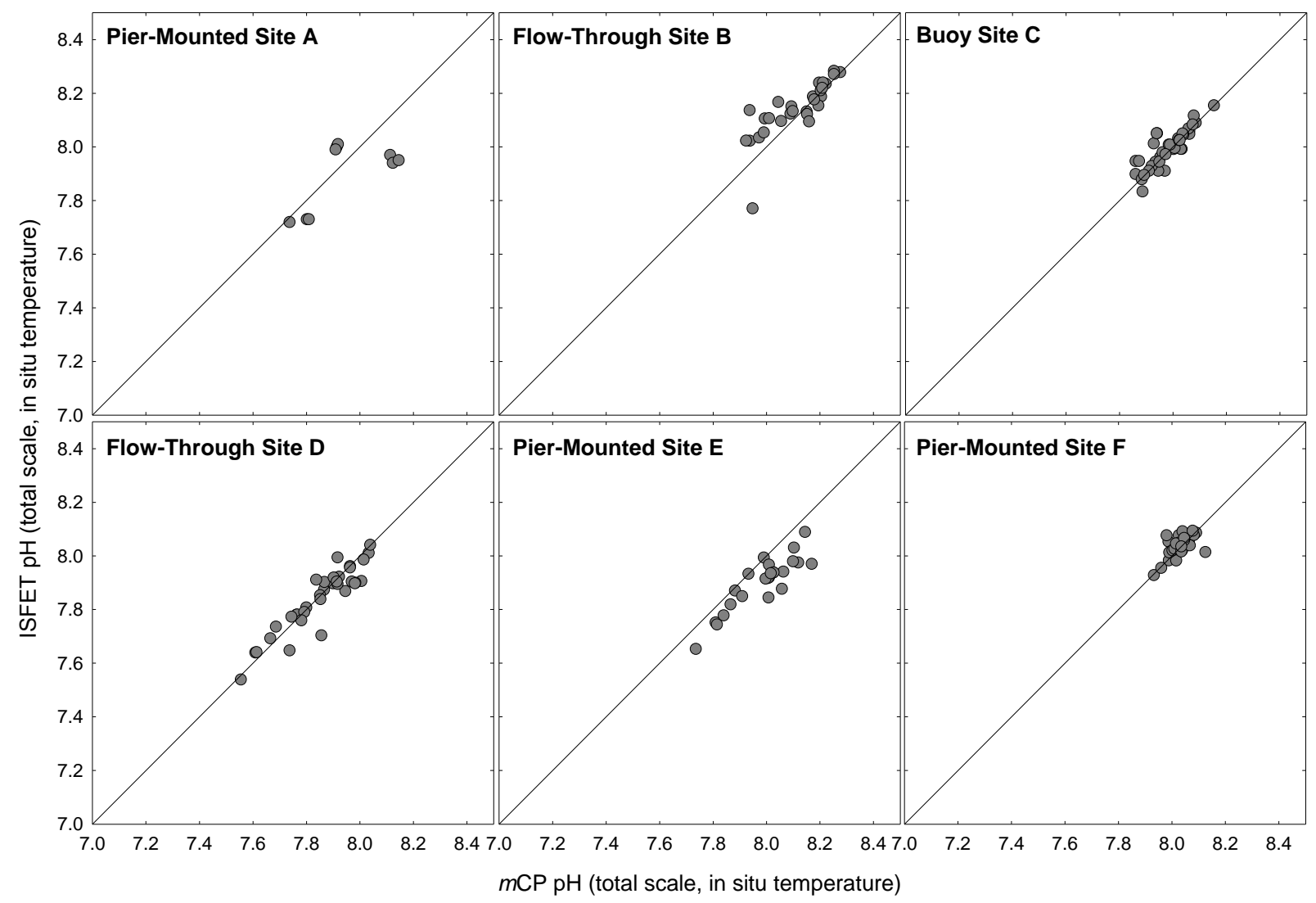

Figure 3. Difference in $\mathrm{pH}$ between ISFET sensor and $\mathrm{pH}$ measured in the laboratory using the $m$-cresol purple ( $m$ CP method) for each site and across sites. 

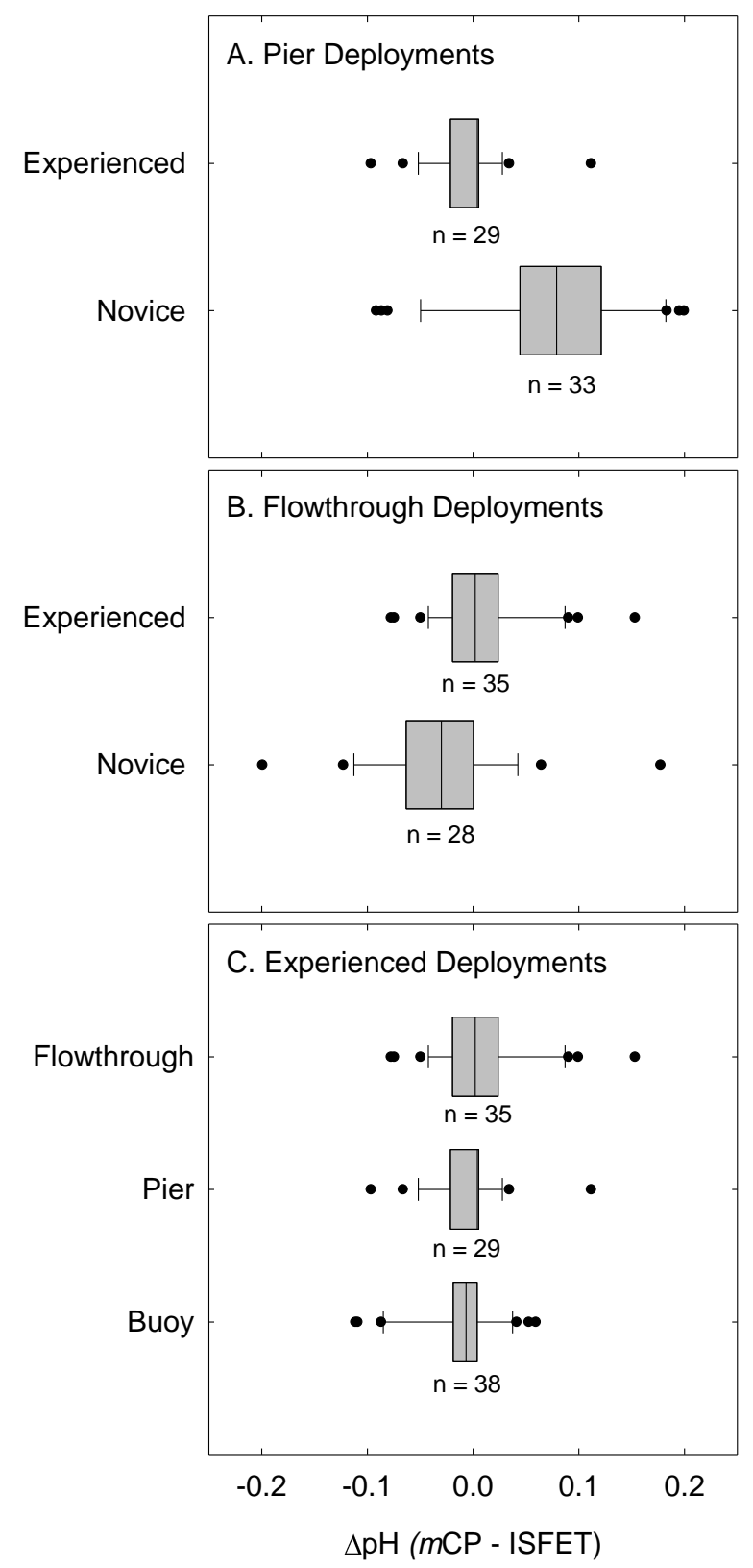

Figure 4. Experienced users had significantly better agreement between ISFET sensor measurements and bottle sample measurements (Mann-Whitney Rank Sum Test) on pier deployments (A., P < 0.001) and in flowthrough systems $(\mathrm{B}, \mathrm{P}=0.004)$. There were no significant differences (Mann-Whitney Rank Sum Test) between experienced operators on the pier, buoy, or flowthrough system deployments (C.). 

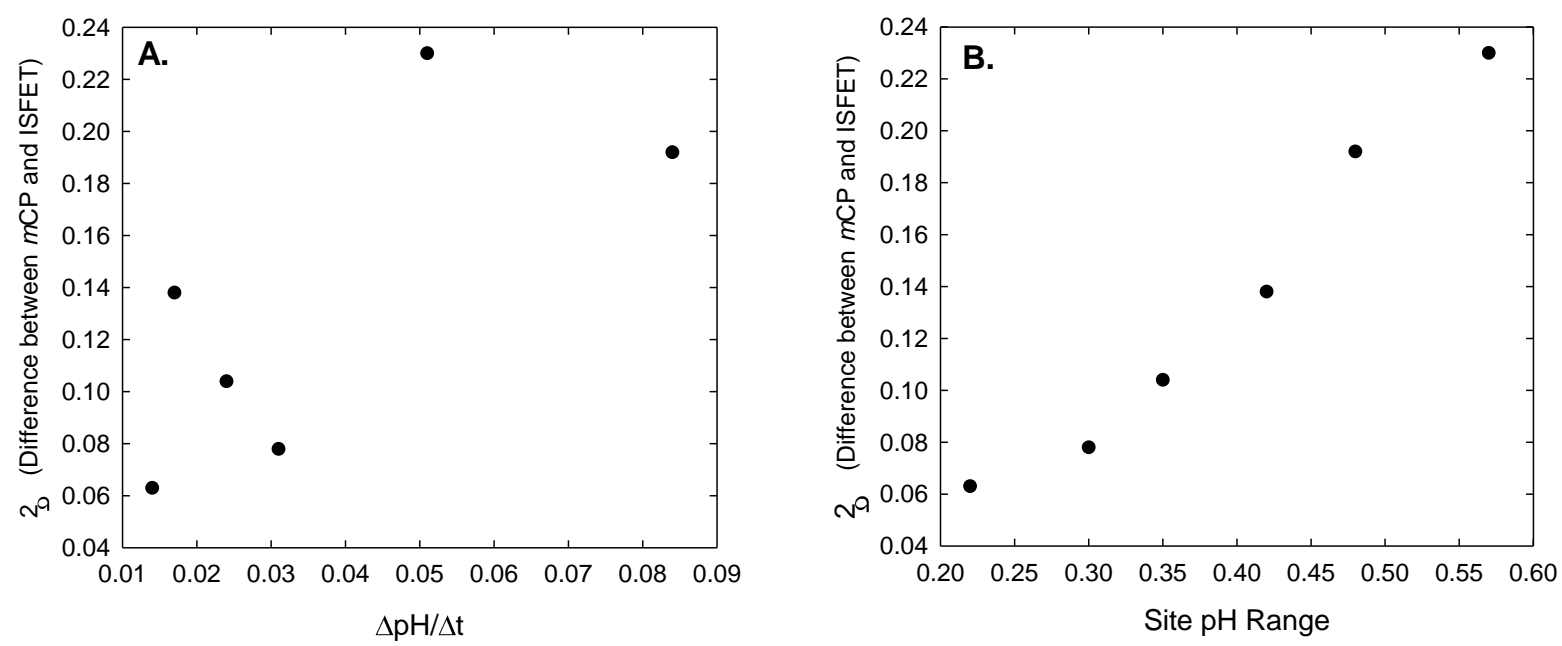

Figure 5. Two sigma standard deviation in the difference between spectrophotometric $\mathrm{pH}(m \mathrm{CP})$ and ISFET sensor $\mathrm{pH}$ increases with both the rate of change in $\mathrm{pH}$ at each site (A) as well as the $\mathrm{pH}$ range at each site $(\mathrm{B})$. 

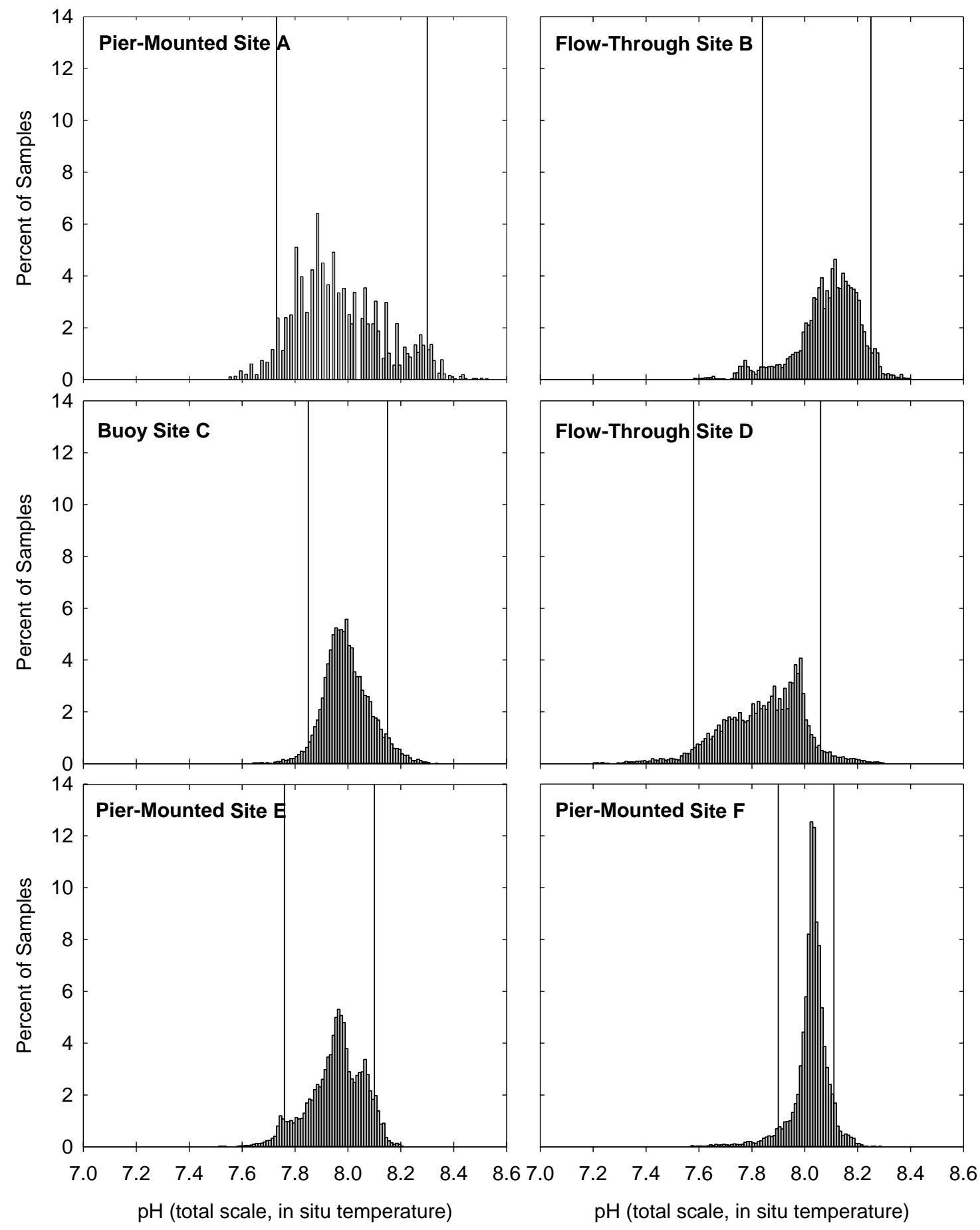

Figure 6. Natural ranges of $\mathrm{pH}$ at each of the 6 sites. Solid black lines represent the $5^{\text {th }}$ and $95^{\text {th }}$ percentile of observed $\mathrm{pH}$ at each site. Shaded red square represents an uncertainty of ISFET sensor measurements of \pm 0.05 around the mean $\mathrm{pH}$ at each site. 